\title{
Wayne J. Urban \\ More Than Science and Sputnik: The National Defense Education Act of 1958
}

Tuscaloosa, Alabama: University of Alabama Press, 2010. ix, 247 pp.

\author{
Kathleen A. Murphey \\ Indiana University-Purdue University Fort Wayne
}

This is archival research at its best. Wayne Urban tells us how he came to write this history of the National Defense Education Act (NDEA) of 1958. Then, he leads us through the lives and beliefs of the leading actors, distills the key ideological issues, and concludes by tying the varying elements of the NDEA debates to issues that are still with us, such as excellence versus equal opportunity, sciences versus non-sciences, and private versus public schools. He makes it clear that these competing ideological positions have been with us since at least the 1950s, but they are being resolved differently today.

From his relatively new position in 2006 as educational historian at the Education Policy Center of The University of Alabama, Urban became aware of the papers of Alabama U.S. Congressman Carl Elliot and Alabama U.S. Senator Lister Hill, two of the original initiators and supporters of the NDEA. From their papers, Urban discovered the key role they played in bringing the NDEA about, as well as the major benefits that The University of Alabama received from that legislation. As liberal Democrats in the South, their story helps elucidate the relationship of states to federal funding of education, the political minefields of race and religion that these liberal politicians had to walk through, and how they interacted with moderate Republicans at the federal level: President Dwight D. Eisenhower and his point person on the development of the NDEA, Elliot Richardson, then Assistant Secretary for Legislation in the Department of Health, Education, and Welfare. In addition, professional educators, top university leaders, and academic scientists also played decisive roles in the struggle over this legislation. We come away with more than a fifty year perspective on federal educational policy. 
Urban maintains that the NDEA was about "More Than Science and Sputnik" for it involved issues about funding priorities in education that we still wrestle with today. He emphasizes the importance of understanding the historical roots of educational funding at the federal level and implies a critique of current ahistorical policymaking. Urban seeks

to show that history could be relevant to the world of education policy, not in any necessarily immediate sense but through the provision of a longer view of education policy issues.... Such a view allows policies to be seen as they evolve and in terms of their precedents and consequences rather than in the cycle of immediacy and success or failure that seems to dominate the policy and policy analysis arena. (ix)

Urban demonstrates this through a careful reading and presentation of the archival papers of four leaders in the crafting of the NDEA legislation: Elliot, Hill, Eisenhower, and Richardson. While the main actors in this drama have different goals for the federal funding of education, those goals ultimately converged in the passage of the NDEA.

The book is strikingly well written. In spite of the fact that there is a wealth of detail in the papers of the major actors in this narrative, it reads like a complicated novel. To weave the massive detail into an elegant narrative, Urban inserts clear markers of where the history is going and where it has been. The consistency of Urban's measured voice also takes the history smoothly forward. Urban states his argument and situates it well relative to other interpretations of the emergence of the NDEA. For the most part he builds on former research about the NDEA, complimenting it with his perspective from Alabama and his insistence that the NDEA is about "More Than Science and Sputnik."

Urban says that his work is "better described as an ideological history of the act rather than a comprehensively legislative, or purely procedural, political history" (1). It is the ideological focus that brings the history to life and also helps Urban tie it to federal educational policy issues since 1958. It is, succinctly, a story of how two liberal Democrats, Elliot and Hill, and two moderate Republicans, Eisenhower and Richardson, were able to work within and react to the climate that Sputnik brought to the public's attention about the readiness of U.S. science to meet national defense challenges, and the preparedness of science education to keep the U.S. in the lead. In the debates that come after 1958, and after the Elementary and Secondary Education Act (ESEA) of 1965, Urban shows us the liberal/moderate ideological coalition growing increasingly conservative during, especially, Reagan's presidency and continuing in the two Bush presidencies. We see how debates about key issues have endured, even if, now, progressive forces are not winning. The conservative forces for excellence and merit seem to be drowning out the forces for equity and opportunity, private schooling seems to be promoted over public, and race and religion still lurk in the background as complicating factors. 
Urban's book was written through early 2008. That date seems important for it was pre-economic downturn, pre-Obama's presidency, pre-Race-to-The-Top; prelimiting of collective bargaining for teachers in some states. Because Urban worries about the impact of the No Child Left Behind Act (2001) and the meteoric rise of ideologically conservative and non-progressive forces in educational policy, one wonders what he would have thought of the more recent developments and how he would have framed his argument if he had finished writing in 2010. Perhaps that is testament to the speed with which federal policies and reforms are currently taking place, and why such a history as this is so urgently needed.

Urban's voice is measured and positive, which serves his purposes well. I wonder, however, if our responses to his history should be so measured. In the distancing of U.S. commitments at a national level from equality, equity, and opportunity - especially at a time when the gulf between haves and have-nots is growing - should we not be horrified/outraged that, whatever steps forward the NDEA made, these progressive forces have been turned on their head, as conservative think tanks and foundations, and a faltering economy, chip away at democratic, public traditions in education? Wayne Urban's research, following the passage of the NDEA in 1958 and the ESEA in 1965, shows the gradual retreat from progressive ideals in the federal funding of education. His book is, in effect, a requiem, beautifully written, for the rise, support, and ultimate decline of progressive educational funding policy at the federal level. One comes away proud of the four protagonists in this story: Elliot, Hill, Eisenhower, and Richardson. They rise as heroes and complex political actors; they provide a vivid, human face to federal educational policy struggles in the late 1950s. The grand historical narrative of Urban's work, however, portends new priorities in federal educational policy that are, to progressives, worrisome.

In sum, this is a powerful history; its integration with ongoing policy issues makes it outstanding. This is Wayne Urban at his best. 